\title{
Larveterapi i sårbehandling
}

\begin{abstract}
Sammendrag
Bakgrunn. Fluelarvers evne til å forhindre sårinfeksjoner og fremme sårheling ble beskrevet allerede på 1800 tallet. Økende problemer med behandlingsresistente sårinfeksjoner og antibiotikaresistente bakterier har ført til fornyet interesse for larveterapi.
\end{abstract}

Materiale og metode. Artikkelen er basert på en gjennomgang av litteratur om larveterapi funnet ved et ikkesystematisk søk i PubMed.

Resultater. Larveterapi er medisinsk bruk av desinfiserte fluelarver, vanligvis larvene til Lucilia sericata, i behandlingen av sår som er resistente mot tradisjonell terapi. Larvene har tre primære virkningsmekanismer. De fjerner nekrotisk vev, dreper bakterier og fremmer sårtilheling. Larvene har bred antibakteriell effekt mot gramnegative og grampositive bakterier, inkludert meticillinresistente gule stafylokokker (MRSA). Larveterapi har vært benyttet med god klinisk effekt $\mathrm{i}$ behandlingen av kompliserte sår i hud og bløtvev assosiert med decubitus, vaskulær insuffisiens, nevropatier, traumer, brannskader og osteomyelitt. Større kontrollerte kliniske studier mangler. Alvorlige bivirkninger i tilknytning til larveterapi har ikke vært beskrevet.

Fortolkning. Larveterapi synes å være et godt og miljøvennlig alternativ $i$ behandlingen av kompliserte nekrotiske sår som ikke responderer på konvensjonell behandling. Larveterapi bør også vurderes tidligere i behandlingsforløpet.
Artikkelen bygger på en 5.-årsoppgave fra medisinstudiet ved Universitetet i Tromsø (1)
Birgit Margrethe Falch

amniculus@hotmail.com

Det medisinske fakultet

Universitetet i Tromsø

9037 Tromsø

\section{Louis de Weerd}

Plastikk- og håndkirurgisk avdeling

Nevro-og ortopediklinikken

Universitetssykehuset Nord-Norge

\section{Arnfinn Sundsfjord}

Avdeling for mikrobiologi og virologi

Institutt for medisinsk biologi

Det medisinske fakultet

Universitetet i Troms $\varnothing$

og

Avdeling for mikrobiologi og smittevern

Medisinsk klinikk

Universitetssykehuset Nord-Norge

I 1829 beskrev Napoleons tidligere sjefskirurg, baron Dominique-Jean Larrey (1766-1842) hvordan sår invadert av fluelarver hadde en rask tilhelningstid uten infeksjoner (2). Klinisk bruk av fluelarver ble første gang beskrevet av sanitetsoffiserene Zacharias og Jones under den amerikanske borgerkrigen (2). Ved å tilføre larver til infiserte traumatiske sår observerte de at larvene fjernet nekrotisk vev og at sårene grodde raskere. Den amerikanske legen William Baer (1872-1931) regnes som grunnleggeren av moderne larveterapi (2). Under første verdenskrig observerte han to soldater som var blitt gjenglemt på slagmarken i én uke. De hadde alvorlige skader og det florerte fluelarver i sårene. Overraskende nok var det verken puss eller andre tegn til infeksjon i sårene. Tvert imot hadde sårene «det vakreste rosa granulasjonsvev man kan tenke seg» (2). Etter krigen utviklet Baer larveterapien videre, og i 1930-årene ble den benyttet på over 300 sykehus i USA (3). Etter introduksjonen av antibiotika i 1940-årene og forbedringer i kirurgisk sårrevisjon forsvant imidlertid det meste av indikasjonsområdet for bruk av medisinske fluelarver (2).

Nærmere 70 år etter antibiotikaenes inntreden i klinisk medisin er multiresistente bakterier et økende problem. Antall mennesker med diabetes mellitus forventes å stige fra 171 millioner i 2000 til 366 millioner i 2030 (4). Terapiresistente sår er en vanlig sykdomskomplikasjon hos denne pasientgruppen. I lys av denne utviklingen har det oppstått en fornyet interesse for larveterapiens muligheter.

Vi ønsker i denne artikkelen å gi en over- sikt over larveterapi som behandlingsform, med vekt på prinsipper, virkningsmekanismer og mulige bruksområder.

\section{Materiale og metode}

Et ikke-systematisk litteratursøk ble gjort i Pubmed. Vi har også innhentet kliniske erfaringer med denne behandlingsformen fra Hudklinikken, Sahlgrenska Universitetssjukhuset, Sverige.

\section{Fluetype og applikasjon}

De flueartene som er aktuelle i larveterapi tilhører ordenen Diptera, såkalte tovinger, og undergruppen Schizophora-Calyptra (5). Disse fluene legger egg i sine vertsdyr, der eggene klekkes og larvene utvikler seg. Larvenes parasittering på vertene kalles myasis. Ut ifra deres forhold til verten kan de deles inn i to grupper: obligate og fakultative parasitter, som henholdsvis kun kan utvikle seg $\mathrm{i}$ en levende vert eller både $\mathrm{i}$ levende og døde verter. Larveterapi er derfor en kunstig indusert og kontrollert form for myasis, der behandleren forsøker å balansere de positive effektene av larvenes sanerende effekt på nekrotisk vev (benign myasis) mot deres potensielt negative effekter på friskt vev (malign myasis) (2).

Fluene som primært benyttes, er de fakultative artene i Calliphoridae-familien (spyfluer), som for det meste lever av åtsel. Hovedsakelig brukes arten Lucilia sericata. Malign myasis er ikke rapportert med denne arten (2). I den kommersielle fremstillingen av larvene blir eggene sterilisert. Larvene klekkes etter 12-14 timer. De er ca. 1-2 mm lange og klare for klinisk bruk. Etter 4-5 dager er de utvokste (ca. $1 \mathrm{~cm}$ ), går over i puppestadiet og slutter å ta til seg næring (6).

Larvene appliseres $\mathrm{i}$ såret omgitt $\mathrm{av}$ et passende stykke hydrokolloid med et hull i midten som tilsvarer sårets form. Hydrokolloidet representerer et grunnlag for bandasjen, beskytter normal hud mot larvenes pro-

\section{Hovedbudskap}

- Larvene til Lucilia sericata blir brukt i behandlingen av behandlingsresistente sår

- Larvene oppløser nekrotisk vev, dreper bakterier og fremmer sårheling

- Larveterapi er effektivt mot en rekke bakterier og gir få bivirkninger 
teolytiske enzymer og hindrer at pasienten kjenner larvenes bevegelser. Alternativt kan sinkpasta brukes rundt sårkanten. Hydrogel har vist seg å ha en hemmende effekt på larvene og bør unngås (6). Larvene påføres deretter i såret, ca. 5-10 per $\mathrm{cm}^{2}$, som så dekkes av et småmasket nett av nylon festet til basen av hydrokolloid. Dette dekkes igjen av et absorberende lag som trekker til seg eksudat fra såret. Ytterst appliseres en gjennomsiktig semipermeabel membran. Larvene fjernes etter ca. tre dager (fig 1). Ut ifra sårets tilstand kan man enten legge på nye larver eller bytte til en konvensjonell bandasje (7). Når man har fått renset såret og oppnådd et tilfredsstillende resultat, kan det lukkes kirurgisk. Riktig diagnose og behandling av underliggende årsaker er en viktig forutsetning for vellykket sårbehandling.

\section{Virkningsmekanismer}

Larvene til L sericata tar til seg næring ved å suge i seg oppløst nekrotisk vev og bakterier (5). Fôring av disse larvene med fluorescensmerkede ampicillinresistente Escherichia coli har vist at larvenes fordøyelsessystem har en baktericid effekt på slike bakterier (3). Proteus mirabilis lever i larvenes tarmsystem som en kommensalist. P mirabilis produserer fenylacetat og fenylacetaldehyd, som har en bred antimikrobiell effekt under sure forhold (8).

Videre er det påvist antibakteriell effekt i sekreter fra L sericata-larver forenlig med tilstedeværelse av antimikrobielle peptider (9). En nylig publisert studie dokumenterte en bred bakteriostatisk effekt i fraksjoner fra slike sekreter (10). Den antibakterielle effekten ble også dokumentert overfor 12 ulike MRSA-stammer, inkludert representanter for epidemiske kloner (10).

Larvene utsondrer en rekke substanser for å optimalisere egne levevilkår. Disse faktorene spiller sannsynligvis også en viktig rolle i sårtilhelingen gjennom fjerning av mikrober og nekrotisk materiale samt danning av granulasjonsvev (2). Videre har in vitrostudier vist at larveekstrakter og sekreter har en vekststimulerende effekt på humane fibroblaster (11). Dette kan medvirke til ny vevsdanning. Det finnes også holdepunkter for at behandling med larveterapi bedrer vevsoksygeneringen og slik fremmer danning av nytt granulasjonsvev (12). Videre skilles det ut ammoniakk som hever $\mathrm{pH}$-verdien og øker aktiviteten til larvenes kymotrypsin- og trypsinliknende proteinaser (13). Dette anses viktig for larvenes evne til å fjerne nekrotisk materiale. Biokirurgi er en ny betegnelse på larveterapi og refererer til larvenes selektive nekrosektomi. Nekrotisk materiale fjernes skånsomt uten at det friske vevet skades (6).

\section{Bruksområder}

Hovedindikasjonen til larveterapi er desinfeksjon og rensing av fuktige, nekrotiske og infiserte sår (6). Larvene er avhengige av
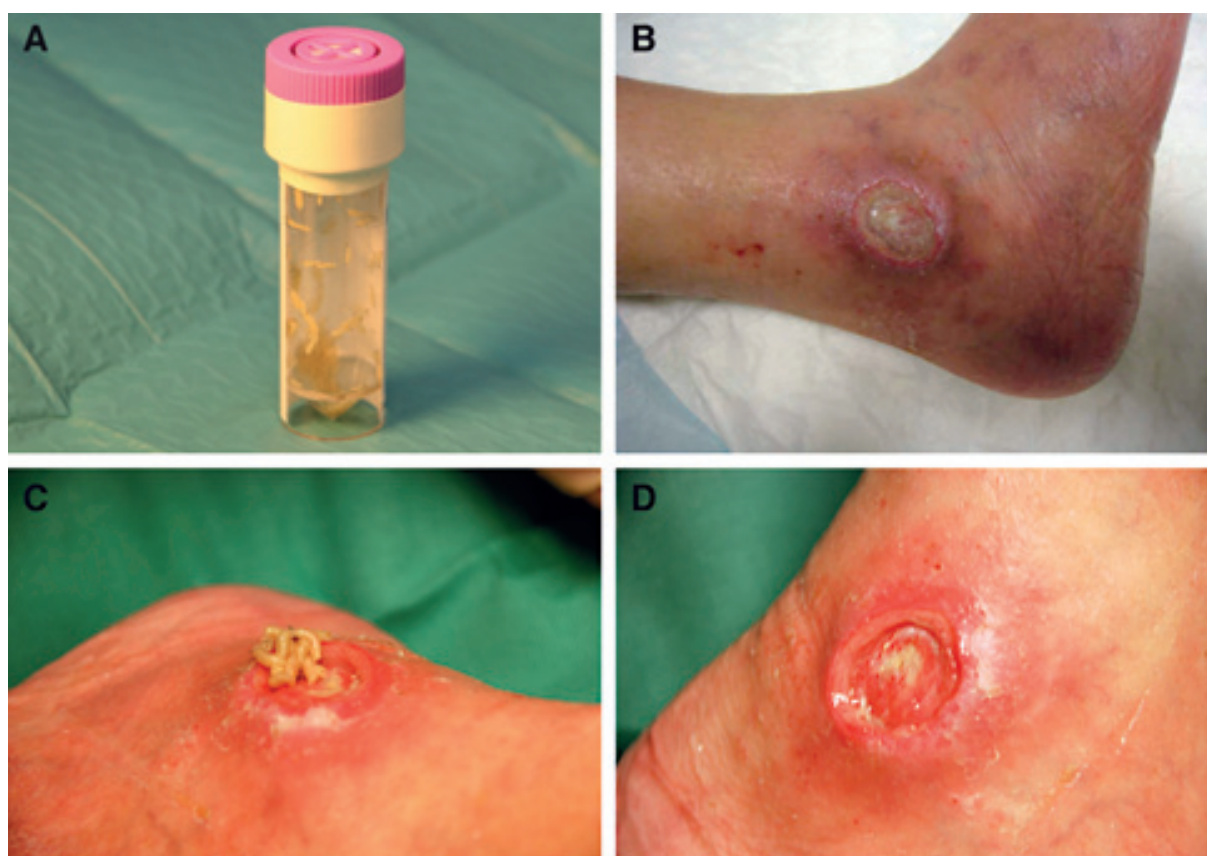

Figur 1 al Nyklekkede larver i transportbeholder. b) Sår på laterale malleol før behandling med larveterapi. c) Etter tre dager fjernes larvene fra såret. De er da rundt $1 \mathrm{~cm}$ lange og har mangedoblet vekten sin. d) Sår på laterale malleol etter tre dagers behandling med larveterapi. Foto Sven Weum og Louis de Weerd. Pasienten har gitt samtykke til at bildene blir publisert

oksygen, og såret må derfor ha en åpning som tillater en tilstrekkelig oksygenering. Larvenes luftinntak er i haleregionen, og de står opp ned i såret for å kunne ta til seg næring. De kan drukne ved kraftig eksudasjon og utilstrekkelig drenasje. Larvene er også avhengig av fuktighet og er derfor mindre effektive i tørre sår. De kan imidlertid brukes mot harde nekroser hvis disse bløtes opp på forhånd og holdes fuktig (14).

Larvene er fotofobe og søker seg nedover i såret, inn i fistelganger og under nekroser. Dette er i utgangspunktet gunstig, men det gjør også at «frittgående» larver ikke kan brukes i sår som kommuniserer med hulrom i kroppen (6). Løsningen på dette problemet er såkalte biobags, der larvene er plassert i lukkede permeable polyvinylposer. Disse posene lar larvenes sekret komme i kontakt med såret. Samtidig kan larvene ta til seg næring fra såret, uten å være i direkte kontakt med såroverflaten (15). Det foreligger imidlertid noen observasjoner som indikerer at biobag ikke gir like gode resultater som når larvene er i direkte kontakt med såret $(16,17)$.

Larveterapi kan være aktuelt ved sår som ikke har respondert på konvensjonell behandling og der kirurgi ikke er hensiktsmessig eller mulig. Behandlingsformen har først og fremst vært benyttet $i$ behandlingen av alvorlige hud- og bløtdelsinfeksjoner assosiert med decubitus, pyoderma gangrenosum, osteomyelitt, vaskulær insuffisiens og nevropati $(2,6,18)$. Larvene brukes normalt ikke i sår der infeksjonen umiddelbart må under kontroll for å berge lemmer og liv. De har også vært benyttet til å rense sår preoperativt og $\mathrm{i}$ behandlingen av postoperative infeksjoner (19).
Kliniske erfaringer kan tyde på at behandlingseffekten er dårligere hos eldre pasienter, ved kronisk iskemi i ekstremitetene og ved dype sår (17). Behandlingseffekten synes ikke å variere med kjønn, overvekt, forekomst av diabetes mellitus, røyking, ASA-klassifisering og sårets lokalisasjon, varighet eller utbredelse $(17,20)$. ASA-klassifikasjon (American Society of Anesthesiologists) innebærer en vurdering av pasientens preoperative tilstand og den risiko et operativt inngrep innebærer for den enkelte pasient.

\section{Kliniske studier \\ Diabetiske fotsår}

Flere kliniske studier har vist at larveterapi har en særlig god effekt på diabetiske fotsår (12, 21-23). Dette er relativt små studier av pasienter med kroniske sår, der 4-29 pasienter hadde diabetes som tilgrunnliggende årsak. Bare én av dem sammenlikner resultatene av larveterapi med konvensjonell sårbehandling (22). Enkeltobservasjoner tyder på at amputasjon har vært unngått som en direkte følge av behandling med fluelarver (24). Diabetikere har en betydelig forhøyet risiko for underekstremitetsamputasjoner $\mathrm{i}$ forhold til normalbefolkningen. Mer enn $50 \%$ av alle amputasjoner blir gjort hos diabetikere, og rundt $85 \%$ av alle amputasjoner hos diabetikere skyldes diabetiske fotsår. Til tross for fremskritt i konvensjonell sårbehandling har man ikke sett nedgang i antall diabetiske amputasjoner de siste årene. I Skandinavia regner vi med 10-11 slike amputasjoner per 100000 innbyggere årlig. Dette tilsvarer 400-500 tilfeller i Norge hvert år. Svenske analyser viser at kostna- 
dene ved behandling av et diabetisk fotsår er estimert til ca. 154000 kroner, mens en amputasjon på lårnivå vil koste 3-4 ganger så mye (25).

Meticillinresistente gule stafylokokker (MRSA) kan kolonisere og infisere kroniske sår. Dette kan gi grunnlag for bruk av særlig bredspektrede og kostbare antibiotika. Det er derfor interessant at man $i$ en studie av 13 pasienter med MRSA-infiserte diabetiske fotsår oppnådde en fullstendig eradikasjon av stafylokokkene etter gjennomsnittlig tre larveapplikasjoner med en behandlingsvarighet på gjennomsnittlig 19 dager (26). Larveterapi bør derfor være et alternativ hvis konvensjonell behandling skulle feile.

\section{Decubitus}

Larveterapi har også vist seg effektivt i behandlingen av decubitus. En sammenliknende studie av 103 pasienter med decubitus behandlet med larveterapi og konservativ behandling viste full tilhelning $\mathrm{i}$ henholdsvis $80 \%$ og $48 \%$ av sårene. Larveterapi hadde en signifikant bedre effekt på fjerning av nekrotisk vev, stimulering av granulasjonsvev og reduksjon i såroverflate sammenliknet med den konservative sårbehandlingen (20).

\section{Andre indikasjoner}

Så langt er larveterapi primært blitt brukt som et siste forsøk der andre behandlingsformer har mislyktes. I en åpen studie av larveterapi hos 25 pasienter med i alt 43 behandlingsresistente sår ble fullstendig revisjon oppnådd i 38 sår. Bare ett sår forble uforandret. Hos fem pasienter som allerede var henvist til amputasjon, ble ekstremitetene varig reddet etter larveterapi (27). Det finnes også indikasjoner på at larvene er velegnet som profylakse mot postoperative infeksjoner i sår som skal behandles med kirurgisk lukking (19). I tillegg er det rapportert at larveterapi kan benyttes i behandlingen av brannsår (28).

Det er anslått at det er publisert 7000 pasientbehandlinger med larveterapi med samsvarende positive resultater (29). Små pasientmaterialer er imidlertid et gjennomgående problem med disse studiene. Man har i lengre tid sett behovet for større, randomiserte studier for å gi påstandene om larvenes effekt et bedre vitenskapelig fundament. Det har imidlertid vist seg å være vanskelig å skaffe den nødvendige finansielle støtten til slike prosjekter. Dette skyldes flere forhold. Gjennomføring av store randomiserte studier er kostbart. På grunn av tidligere publikasjoner kan man ikke ta patent på L sericata som art $\mathrm{i}$ behandlingen av kroniske sår. Det er imidlertid mulig for sykehus å avle larvene selv, slik som man for eksempel har valgt å gjøre ved Sahlgrenska Universitetssjukhuset i Göteborg. Disse faktorene medfører mindre interesse for større kliniske studier initiert av legemiddelindustrien, men burde legge forholdene godt til rette for stu- dier finansiert av det offentlige. Evalueringen av effekten av larveterapi er heller ikke uproblematisk. Det er svært vanskelig å blinde pasient eller behandler ved bruk av larveterapi. Det er derimot mulig å blinde den som evaluerer (30).

\section{Bivirkninger}

Alvorlige bivirkninger med larveterapi er ikke beskrevet (14). Det er rapportert en økt blødningstendens i sår som behandles med fluelarver (14). Dette skyldes sannsynligvis proteolytiske enzymers innvirkning på et rikt vaskularisert granulasjonsvev. Det frarådes derfor at larveterapi brukes $\mathrm{i}$ sår med større synlige kar, med nekrotiske karvegger eller hos pasienter med alvorlige koagulopatier (15).

Mange pasienter opplever redusert sårsmerte under larvebehandlingen, men enkelte kan oppleve økte smerter (21). Vanligvis lar smertene seg lindre med lettere analgetika og vil alltid opphøre hvis behandlingen seponeres (2). Teoretisk kan pasienten utvikle kontaktallergi mot larveproteiner, men dette er så langt ikke beskrevet (14). Larvene skiller ut ammoniakk, men et forhøyet nivå av ammoniakk i serum er ikke observert hos mennesker. Man anbefaler imidlertid å måle ammoniakknivået hvis en pasient skulle få høy feber, endret bevissthet eller andre systemiske symptomer under pågående larveterapi (15). Det er rapportert at larvene har en manglende antimikrobiell effekt på enkelte Proteus- og Pseudomonas-arter (15) Disse bakterieartene kan dermed få en selektiv fordel når larvene fjerner den konkurrerende bakteriefloraen (15). Nyere studier har imidlertid dokumentert antibakterielle effekter av larvesekret mot Pseudomonas aeruginosa (9). Det er fullt mulig å kombinere larveterapi med systemisk antibiotikabehandling basert på en tidligere tatt dyrkingsprøve (15)

\section{Holdninger til larveterapi}

Fluer, og fluelarver i særdeleshet, er ikke videre velansett $i$ vår kultur. Fluelarver er forbundet med smittefare, forråtnelse og død. Deres naturlige habitat er i kadavre og annet råttent organisk materiale. Flere rapporter viser at helsepersonell er skeptisk til larveterapi. Negative holdninger hos helsepersonellet har vært rapportert å være den faktoren som medførte størst problemer i gjennomføringen av studier av larveterapieffekt (20). Slike holdninger kan påvirkes gjennom grundig opplæring og innsyn i klinisk bruk av larveterapi $(14,28)$.

Studier har vist at pasienter som får tilbud om larveterapi generelt sett er positive til behandlingsformen $(21,28,31)$. Sahlgrenska Universitetssjukhuset i Göteborg fikk svært mange henvendelser fra pasienter som ønsket larveterapi etter et oppslag i svenske medier om slik behandling (C. Hansson, personlig meddelelse). I en spørreskjemaundersøkelse blant 37 pasienter som hadde fătt larveterapi, svarte 33 at de ville takke ja til et slikt behandlingstilbud dersom det ble aktuelt i fremtiden (31).

\section{Kommersielle produkter}

I 2003 klassifiserte Food and Drug Administration (FDA) i USA medisinske larver som medisinsk utstyr. I januar 2004 godkjente FDA markedsføring av medisinske fluelarver. Larveterapi er reseptbelagt i USA (32). I Storbritannia har fluelarver vært kommersielt tilgjengelig til sårbehandling siden midten av 1990-årene (27). Også her er larvene reseptbelagt. EU har klassifisert larvene som et legemiddel, men det er ikke utstedt lisens for markedsføring.

I Skandinavia har Sahlgrenska Universitetssjukhuset et eget larvelaboratorium. Larvene selges til selvkost til resten av Sverige og Norden for øvrig. I 2007 ble det formidlet larver til totalt 185 behandlinger i Sverige (M. Lignell, personlig meddelelse). I Norge har Statens legemiddelverk klassifisert larvene som et legemiddel. Larveterapi kan benyttes ved å søke Statens legemiddelverk om godkjenningsfritak (I. Aaløkken, personlig meddelelse).

\section{Konklusjon}

Millioner av år med utvikling og tilpasning har gjort larvene i stand til effektivt å kunne motstå bakterielle infeksjoner. Fluelarvene ser også ut til å holde tritt med bakterienes utviklingsmessige mottrekk mot tradisjonelle antibakterielle strategier. Vårt kulturelle syn på fluer og larver som selve antitesen til helse og som legemliggjøringen av død bidrar uten tvil til å bremse utbredelsen av larveterapi. Den økte bruken av larveterapi og intensiverte forskningen på dette området $\mathrm{i}$ vestlige land kan derfor ses på som en sterk indikasjon på larvenes terapeutiske effekt.

Larveterapi har hittil ofte vært mest brukt som et siste alternativ $\mathrm{i}$ behandlingen av kompliserte sår. Studier og klinisk erfaring tyder på at larveterapi kan være effektivt mot ellers behandlingsresistente hud- og bløtdelsinfeksjoner, med særlig god virkning på tilheling av diabetiske sår. Man har vist, både klinisk og eksperimentelt, at fluelarver bidrar til eliminering av nekrotisk vev, sårdesinfeksjon gjennom drap av mikrober og bedret sårheling. For hvert mislykket behandlingsforsøk forverres utgangspunktet for neste behandlingsform. I lys av slike erfaringer kan man vurdere å prøve larvene i tidligere stadier av behandlingsforløpet. Forkortet behandlingstid vil være av stor betydning for den enkelte pasient og vil gi økonomiske innsparinger.

Oppgitte interessekonflikter: Ingen 


\section{Litteratur}

1. Falch BM. Maggotterapi. Studentoppgave. Tromsø: Medisinsk fakultet, Universitetet i Tromsø, 2008.

2. Sherman RA, Hall MJ, Thomas S. Medicinal maggots: an ancient remedy for some contemporary afflictions. Annu Rev Entomol 2000; 45: 55-81.

3. Mumcuoglu KY, Miller J, Mumcuoglu M et al. Destruction of bacteria in the digestive tract of the maggot of Lucilia sericata. J Med Entomol 2001; 38: 161-6.

4. Wild S, Roglic G, Green A et al. Global prevalence of diabetes - estimates for the year 2000 and projections for 2030. Diabetes Care 2004; 27: 1047-53.

5. Chinery M. Insektsleksikon i farger. Oslo: Tiden, 1978.

6. Wollina U, Karte K, Herold $C$ et al. Biosurgery in wound healing - the renaissance of maggot therapy. J Eur Acad Dermatol Venereol 2000; 14 : 285-9.

7. Sherman RA. A new dressing design for use with maggot therapy. Plast Reconstr Surg 1997; 100: 451-6.

8. Lerch $\mathrm{K}$, Linde $\mathrm{HJ}$, Lehn $\mathrm{N}$ et al. Bacteria ingestion by blowfly larvae: an in vitro study. Dermatology 2003; 207: 362-6.

9. Huberman L, Gollop N, Mumcuoglu KY et al. Antibacterial properties of whole body extracts and haemolymph of Lucilia sericata maggots. J Wound Care 2007; 16: 123-7.

10. Bexfield A, Bond AE, Roberts EC et al. The antibacterial activity against MRSA strains and other bacteria of a $<500$ Da fraction from maggot excretions/secretions of Lucilia sericata (Diptera: Calliphoridae). Microbes Infect 2008; 10: 325-33.

11. Prete PE. Growth effects of Phaenicia sericata larval extracts on fibroblasts: mechanism for wound healing by maggot therapy. Life Sci 1997; 60: $505-10$.

12. Wollina U, Liebold K, Schmidt WD et al. Biosurgery supports granulation and debridement in chronic wounds - clinical data and remittance spectroscopy measurements. Int J Dermatol 2002; 41: 635-9.

13. Chambers S, Woodrow S, Brown AP et al. Degradation of extracellular matrix components by defined proteinases from the greenbottle larva Lucilia sericata used for the clinical debridement of nonhealing wounds. Br J Dermatol 2003; 148: 14-23.

14. Wolff $H$, Hansson $C$. Renässans för fluglarver vid behandling av sår. Läkartidningen 1998; 95 : 4468-9.

15. Fleischmann W, Grassberger M, Sherman RA Maggot therapy - a handbook of maggot-assisted wound healing. Stuttgart: Georg Thieme Verlag, 2004.

16. Steenvorde P, Jacobi CE, Oskam J. Maggot debridement therapy: Free-range or contained? An invivo study. Adv Skin Wound Care 2005; 18: 430-5.

17. Steenvoorde $P$, Jacobi CE, Van Doorn L et al. Maggot debridement therapy of infected ulcers: patient and wound factors influencing outcome a study of 101 patients with 117 wounds. Ann R Coll Surg Engl 2007; 89: 596-602.

18. Jukema GN, Menon AG, Bernards AT et al. Amputation-sparing treatment by nature: «surgical» maggots revisited. Clin Infect Dis 2002; 35: 1566-71.

19. Sherman RA, Shimoda KJ. Presurgical maggot debridement of soft tissue wounds is associated with decreased rates of postoperative infections. Clin Infect Dis 2004; 39: 1067-70.

20. Sherman RA. Maggot versus conservative debridement therapy for the treatment of pressure ulcers. Wound Repair Regen 2002; 10: 208-14.

21. Wolff H, Hansson C. Larval therapy - an effective method of ulcer debridement. Clin Exp Dermatol 2003; 28: 134-7.

22. Sherman RA. Maggot therapy for treating diabetic foot ulcers unresponsive to conventional therapy. Diabetes Care 2003; 26: 446-51.
23. Sherman RA, Sherman J, Gilead L et al. Maggot debridement therapy in outpatients. Arch Phys Med Rehabil 2001; 82: 1226-9.

24. Jukena GN, Menon AG, Bernards AT et al. Amputating-sparing treatment by nature: «surgical» maggots revisited. Clin Infect Dis 2002; 35: $1566-71$.

25. Tennvall GR, Apelqvist J, Eneroth M. Costs of deep foot infections in patients with diabetes mellitus. Pharmacoeconomics 2000; 181: 225-38.

26. Bowling FL, Salgami EV, Boulton AJ. Larval therapy: A novel treatment in eliminating methicillinresistant Staphylococcus aureus from diabetic foot ulcers. Diabetes Care 2007: 30: 370-1.

27. Mumcuoglu KY, Ingber A, Gilead A et al. Maggot therapy for the treatment of intractable wounds. Int J Dermatol 1999; 38: 623-7.

28. Namias N, Varela JE, Varas RP et al. Biodebridement: A case report of maggot therapy for limb salvage after fourth-degree burns. J Burn Care Rehabil 2000; 21: 254-7.

29. Thomas S. Cost of managing chronic wounds in the UK, with particular emphasis on maggot debridement therapy. J Wound Care 2006; 15: 465-9.

30. Sherman RA, Wyle F, Vulpe M. Maggot therapy for treating pressure ulcers in spinal cord injury patients. J Spinal Cord Med 1995; 18: 71-4.

31. Steenvorde $P$, Buddingh TJ, van Engeland $A$ et al. Maggot therapy and the «yuk» factor: an issue for the patient? Wound Repair Regen 2005; 13: 350-2.

32. U.S. Food and Drug Administration. Medical devices. October 2007 510(k) clearances. www.fda.gov/ MedicalDevices/ProductsandMedicalProcedures/ DeviceApprovalsandClearances/510kClearances/ ucm083781.htm (21.10.2008).

Manuskriptet ble mottatt 10.12. 2008 og godkjent 28.5. 2009. Medisinsk redaktør Åslaug Helland. 